On the other hand these were necessarily naval ships and as such quite unsuited to the scientists' requirements. The fact that the Navy held command, moreover, meant that surveying was accorded priority throughout. Worst of all, the Expedition's leader was high-handed and officious, even forbidding the conchologist member to take specimens below decks, thereby compelling him to restrict his collections severely.

Lieutenant Charles Wilkes, indeed, is both hero and villain of the story. But for his forcefulness and determination the Expedition would never have accomplished so much; yet, ever-conscious of the political purpose its research was meant to serve (not for nothing was he the greatnephew of the English politician of the same surname), he boxed in the taxonomists appointed to work up the collections with stultifying edicts. The reports, he insisted, must all be written by Americans in America - and, what is more, only in its capital city. Yet Washington at that date had no scientific library or reference collections of any consequence. Only after repeated protests did he consent to material being referred to specialists overseas.

Even when the scientific work was completed, its publication was ludicrously botched: the 19 volumes of reports and atlases in which it was embodied were limited to a print run of only 100 copies. The collections meanwhile were left without a home for all of 16 years, subjected to pilfering by Congressmen and other public figures who helped themselves to specimens as souvenirs. First offered to the Smithsonian in 1846 , only to be rejected as too expensive to curate, they were finally consigned there in 1858 by a Congress bereft of further patience or ideas. Even then their fate was not necessarily happy. Most of the crustacean material perished while on loan to Chicago in the great fire of 1871 . Symptomatically, too, the unpublished report on the fishes produced by Louis Agassiz was lost in the bowels of the museum for well over a century.

Despite all this, impressive additions to knowledge resulted. The zoological specimens alone turned out to contain nearly 2,000 new species. Dana's geological work, in particular, was to have an enduring influence, his observations in the Pacific anticipating the recent discoveries of plate tectonics. Many years were to pass, too, before the survey findings were superseded. Appropriately, indeed, even as late as the Second World War when the US marines came to invade Tarawa it was the chart made by the Wilkes Expedition that proved to be the only one available to guide them.

David E. Allen, Lesney Cottage, Middle Road, Winchester, Hampshire SO22 $5 \mathrm{EJ}$, is a past President of the Society for the History of Natural History and author of The Naturalist in Britain: A Social History (Allen Lane, 1976).

\section{Curiosities of crime in medicine}

\author{
H.R.F.Keating
}

Surgeons at the Bailey: English Forensic Medicine to 1878. By Thomas Rogers Forbes. Yale University Press:1986. Pp.255. \$26, £20.

History has a terrible habit of lapsing into anecdote, and one never knows whether to cry or to laugh. This ambivalence applies just as firmly when the history is the history of science. Thomas Rogers Forbes, Professor Emeritus of Anatomy and advisor in medical memorabilia at Yale, has had the worthily academic notion of outlining a history of forensic medicine in Britain. He uses chiefly the Old Bailey Sessions Papers, records of trials at what is now the Central Criminal Court from 1684 up to an arbitrary finishing point of 1878 .

These papers are one of the few sources we have for seeing what doctors or embryo medical scientists did and thought when they were brought into rough contact with the varied forms of human criminality. So far so good. Professor Forbes has deived into them with persistence and, with footnotes and bibliography (13 smallprint pages), he has laid down what could have been a formidable account.

But, alas, there is a falling-away from the ideal. Fundamentally, the material for a proper account of the gradual introduction of scientific method into English criminology is not available in the Sessions Papers nor in such other accounts as Professor Forbes from time to time quotes. Furthermore he has chosen to present what evidence he has, not in one sweep, but piecemeal, with potted histories of advances in the detection of blunt instrument injuries, of asphyxia, of sexual offences, of poisoning, of insanity and of a score of other minor aspects.

So it is hard to get much sense of the development of forensic medicine as a whole. On the other side of the coin, the book is simultaneously a tremendous hotch-potch of curiosities and comicalities. Bedside reading for a month, if you can take the odd references to inflammation of the ileum and, indeed, to peine forte et dure, an early scientific approach to finding the truth by squashing a suspect till he talked.

The fact is that murder is as much risible as it is horrific, I suppose because for many of us the funny side is the only way we dare look on the possible prospect of our own violent demise. So we get the socalled Resurrection Men who supplied bodies for anatomical study by digging them up or on occasion doing in the living. Thus the poet Thomas Hood wrote,
Don't go and weep upon my grave And think that there I be.

They haven't left an atom there Of my anatomie.

We get, too, such curiosities as cruenation. Cruenation is the belief that if a murderer can be made to touch the corpse of his victim the wounds will at once bleed. "See", wrote Shakespeare, "dead Henry's wounds Open their congeal'd mouths and bleed afresh". And in 1658 a Major Strangeways was put to this test, passed it triumphantly - and then succumbed under the peine forte, thus sacrificing himself to prevent his property being forfeit to the Crown.

Other speculation-causing titbits include the fact that Addison's Disease is named after Dr Thomas Addison, who actually confused that malady with another (read the footnotes). Or some vicious textbook reviewing in the early 1800 s in which accusations of bad grammar played as dominant a part as challenges to experimental conclusions.

But perhaps the most savourable pages come in the various accounts of attempts on the life of Queen Victoria. There was Edward Oxford, a mulatto pot-boy who, in 1840 , shot twice at Her Majesty, probably with pistols without bullets, and, out of a contradictory plethora of medical evidence, was found insane. (Because he was tried for treason rather than attempted murder he was allowed Counsel without payment.) In the Bethlehem Hospital he learnt six languages, chess, carpentry, the violin and knitting, as well as meeting George Hadfield who, convinced he was King George III and wanting to commit suicide, had fired at the real George III and missed

Robert Pate, who in 1850 merely whammed Her Majesty on the head with a walking-stick, inflicting only a cut, was luckier. Life being odder than fiction, he was arrested by the selfsame policeman who had seized M'Naughten, the errorprone assassin of Robert Peel's secretary and origin of the long-held M'Naughten Rules for defining insanity. Pate was found guilty and not insane - the Judge happened to disagree with the M'Naughten formulations - but was merely sentenced to seven years' transportation. A mad world, my masters - in every sense.

H.R.F. Keating, 35 Northumberland Place, London W2 5AS, UK, is a crime novelist and creator of Inspector Ghote of the Bombay CID. His most recent book is Under a Monsoon Cloud (Hutchinson, 1986).

\section{New in paperback}

- The Limits of Science, by Peter Medawar, a characteristically short, incisive and elegant account of the place of science in the modern world. Publisher in Britain is Oxford University Press, price is $£ 3.95$. The hardback edition was reviewed by Lewis Thomas in Nature 312, 203 (1984). 